Mеталлофиз. новейшие технол. / Metallofiz. Noveishie Tekhnol. (C) 2014 ИМФ (Институт металлофизики 2014 , т. 36, № 11, сс. 1561-1569

Оттиски доступны непосредственно от издателя

им. Г. В. Курдюмова НАН Украины)

Фотокопирование разрешено только

Напечатано в Украине.

в соответствии с лицензией

PACS numbers: 06.60.Vz, 62.20.fg, 62.20.Qp, 81.20.Vj, 81.40.Jj, 81.40.Np, 81.70.Bt

\title{
Investigation of Changes in Mechanical Properties and Microstructures of Mild Steel Joint by Oxy-Hydrogen Welding
}

\author{
H. Ates, M. E. Cakır*, A. Kurt, I. Uygur**, and M. Turker \\ Gazi University, Faculty of Technology, \\ 06500 Ankara, Turkey \\ Department of Metallurgy and Materials Engineering, \\ 06500 Ankara, Turkey \\ "Industrial High School of Golbasi, \\ Haymana Caddesi 275, \\ Ankara, Turkey \\ *Duzce University, \\ Faculty of Engineering, \\ 81620 Duzce, Turkey
}

In this paper, in order to see weldability behaviour of mild steels joint by the oxy-hydrogen welding technique, an investigation of changes in mechanical properties and microstructures of mild steel is carried out. The specimens with $1.5 \mathrm{~mm}$ thickness and $125 \mathrm{~mm}$ length are welded by using both the oxyhydrogen and oxy-acetylene gases. Microstructural analysis is carried out on the cross sectional area of the welding zone in order to compare the changes in weld metals and the heat affected zones in terms of the welding gases. Experimental results of the tensile strength and microhardness obtained with mechanical tests show that samples welded with oxy-acetylene exhibited $10 \%$ higher yield strength than that of the samples welded with oxy-hydrogen. However, the oxy-hydrogen welding technique can be used as an alternative to the oxy-acetylene welding, since it has advantageous of being clean and economic.

С целью выяснения качества сварного шва на малоуглеродистой стали, полученного водород-кислородной сваркой, проведено исследование изменений механических свойств и микроструктуры данного типа стали. Образцы толщиной 1,5 мм и длиной 125 мм сваривались как водородкислородной, так и ацетиленокислородной сваркой. Был проведён микроструктурный анализ поперечного сечения зоны сварки с целью сравнения изменений в металле шва и зоне термического влияния в зависимости от сварочного газа. Экспериментальные результаты по пределу прочности при растяжении и микротвёрдости, полученные при механических испытаниях, показали, что образцы, сваренные ацетиленокислородной свар- 
кой, имеют прочность при растяжении на 10\% выше, чем водородкислородной. Однако водород-кислородная сварка может быть использована как альтернатива ацетиленокислородной сварке, так как она имеет преимущества по чистоте и экономичности.

3 метою з'ясування якости зварюваного шва на маловуглецевій сталі, виробленого водневокисневим зварюванням, виконано дослідження змін механічних властивостей і мікроструктури даного типу сталі. Зразки товщиною у 1,5 мм та довжиною у 125 мм зварювалися як водневокисневим, так і ацетиленокисневим зварюванням. Виконано мікроструктурну аналізу поперечного перерізу зони зварювання з метою порівняння змін у металі шва та зоні термічного впливу в залежності від зварювального газу. Експериментальні результати стосовно границі міцности при розтягу та мікротвердости, одержані під час механічних випробувань, показали, що зразки, зварені ацетиленокисневим зварюванням, мають міцність при розтягу, на 10\% вищу, ніж зварені водневокисневою газовою сумішшю. Однак водневокисневе зварювання може бути використано як альтернатива ацетиленокисневому зварюванню завдяки його перевазі за чистотою та економічністю.

Key words: microstructure, tensile strength, microhardness, mild steel, oxyhydrogen.

(Received March 12, 2014; in final version, April 1, 2014)

\section{INTRODUCTION}

Carbon steel is one of the most consumable metals holding approximately $94 \%$ of the annual steel production in USA. The relatively limited corrosion resistance of the carbon steel does not change the fact that it is used in marine applications, pipelines, transport and domestic applications. However, it was shown that green inhibitors could be used to extend corrosion life of low carbon steel [1].

The importance of welding for the global world economy is well known. The welding is a major step in the fabrication and maintenance of the components in building, aerospace and car and transportation industries. Although the welding technology has been progressively improving as well as the newly developed and competitive methods applied for joining structural components, gas welding still remains one of the most important methods used for connecting elements in many industrial areas. Most of fusion welding techniques are used in filler metals. In oxy-gas welding, two kinds of gases are used. While one is known as flammable, the other is burner. The welding system contains gas tubes, pressure regulators, hose and welding bits. This welding technique can be applied as a fusion welding or brazing of several metals [2-4]. It has many advantages like being easy to apply, cheap, and the possibility of using thin and thick parts [5, 6]. However, the major 
drawback of many fusion-welding techniques is that the non-uniform heat input leads to deformation and distortion. An occurrence of residual stresses in the structure can be problematic for the several standpoints. The localized heating and non-uniform cooling during welding result in a complex distribution of residual stress in the joint. In many countries, fossil fuels are still used, such as coal or oil, which results in environmental pollution. Recently, numerous activities have focused on the use of hydrogen as an alternative energy source, mainly due to high energy prices, limited fossil fuel resources and their areas of occurrence, as well as due to the state of the environment. Renewable energy sources are more attractive and seem to be a fundamental solution to the above problems. Therefore, hydrogen is the most serious candidate in this respect. It can be obtained from chemical synthesis of carbon, water and natural gas or from practically endless stocks such as the distilled water [7, 8]. Recent advances in the electrolysis process for obtaining welding gases from water have made oxy-gas welding again attractive [9]. Since mechanical properties and hardness values for these gases are quite similar, oxy-hydrogen can take place instead of oxy-acetylene because its cheap and easy applications [10].

In this study, the mild steel is welded by both oxy-acetylene gas and oxy-hydrogen gas welding techniques. A comparison is made between two techniques with respect to the mechanical properties and microstructure of the mild steel.

\section{MATERIALS AND METHODS}

A torch fitted with 1-2 mm nozzle tip is used to provide a flame for both oxy-acetylene and oxy-hydrogen welding procedure. Oxyhydrogen generator is generally used to weld ferrous and nonferrous metals [11]. Chemical composition of the base metal (AISI 1010) to be welded is given in Table 1 . A wire having same chemical composition with the base metal is used as filler. Two specimens with $125 \times 80 \times 1.5$ $\mathrm{mm}$ dimensions were welded to each to form samples. Tensile and bending tests are performed at room temperature. Tensile tests are carried out on Instron MLF type machine with $50 \mathrm{kN}$ capacity and tensile speed is $0.5 \mathrm{~mm} / \mathrm{min}$. For each case, three samples are tested and their average values are used for comparison. For metallographic examinations, the samples were cut mechanically from welded zone into two pieces called as microstructural samples and then these samples were hot mounted in bakelite. After grinding them using rough and fine emery and polishing, the samples are etched in chemical solution of $70 \% \mathrm{HCl}$ and $30 \% \mathrm{HNO}_{3}$. Microstructures of the samples are examined using an optical microscopy and SEM. Hardness measurements are carried out using Instron Vickers hardness measurement machine under the $1 \mathrm{~kg}$ load. On each sample, four hardness values are obtained 
TABLE 1. Chemical composition of the AISI 1010 mild steel.

\begin{tabular}{c|c|c|c|c|c|c}
\hline Element & $\mathrm{C}$ & $\mathrm{Mn}$ & $\mathrm{Si}$ & $\mathrm{P}$ & $\mathrm{S}$ & $\mathrm{Fe}$ \\
\hline Weight (\%) & 0.115 & 0.385 & 0.047 & 0.020 & 0.005 & Balance \\
\hline
\end{tabular}

and then average value of them is calculated.

\section{RESULTS AND DISCUSSIONS}

\subsection{Tensile Test Results}

Oxy-hydrogen welded tensile test specimens and their fracture regions are shown in Fig. 1, $a$, and Oxy-acetylene welded specimens are shown in the Fig. 1, $b$. It can be seen that except for A1 specimen, other specimens are failed without the welding fusion zone indicating of welljoined process. Almost all specimens are significantly necked in the base metal because of high ductility. Typical stress-strain curves of oxy-hydrogen and oxy-acetylene welding are shown in Fig. 2, $a, b$. It is well known that the yielding point in mild strength is distinguishable in stress-strain curves since it appears as an upper and lower yield point on the curve. This behaviour occurs because of the nitrogen gas, which causes as a defect and rapid crack growth in that particular microregion. Usually, the yield point can be associated with small amounts of interstitial or substitutional impurities. For example, it has been shown that almost complete removal of carbon and nitrogen from low-carbon steel by wet-hydrogen treatment will remove the yield point. However, only about 0.001 percent of either of these elements is required for an appearance of the yield point where dislocations are strongly pinned, such as by carbon and nitrogen in iron, new disloca-
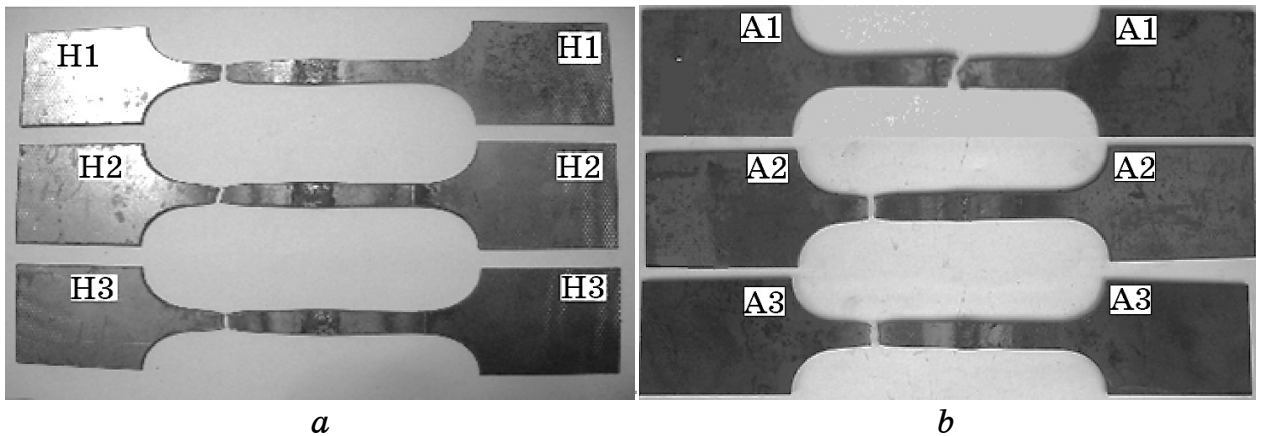

Fig. 1. Tensile test specimens of mild steel for oxy-hydrogen welding $(a)$ and for oxy-acetylene welding $(b)$. 

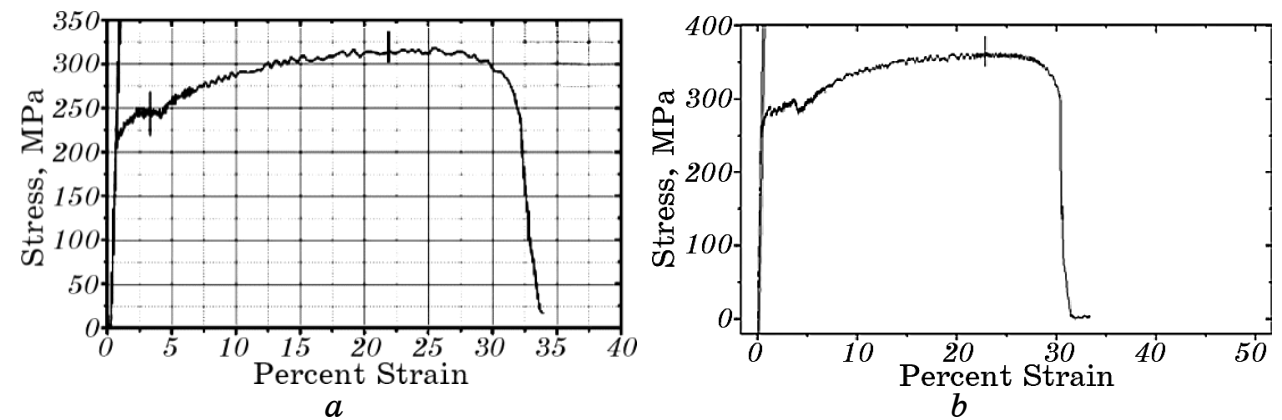

Fig. 2. Typical stress-strain curve of mild steel for oxy-hydrogen welded specimen $(a)$ and oxy-acetylene welded specimen $(b)$.

tions must be generated to allow the flow stress to drop [12]. The tensile properties of average values are given in Table 2 . It is noted that, for oxy-acetylene weldments, the yield strength and Ultimate Tensile Strength (UTS) are significantly higher than those for oxy-hydrogen welded specimens are. However, there is not significant effect of welding process on the ductility. Besides, elastic behaviour of the oxyhydrogen welded specimen is significantly lower than that of oxyacetylene welded specimen, but this reduction is recovered in the plastic region, where both results are almost all overlapped.

The structure of a typical oxy-acetylene flame consists of three easily recognized zones, namely, inner cone zone, acetylene feather (middle zone), and outer flame zone. In the acetylene feather, the excess acetylene is at high temperature and under reducing atmosphere. This leads to complex chemical reactions and the formation of several types of hydrocarbon compounds, which are not negligible for the welding process [13]. It is obvious that tensile properties of the materials are influenced by the flammable gas content.

Carbon is the most crucial element affecting the mechanical properties of steel. Hence, acetylene includes some amount of carbon, which can diffuse in the structure during welding and can change the microstructure of the heat-affected zone. Carbon affects the formation of various phases, namely, cementite and even pearlite in the microstructure.

TABLE 2. Tensile properties of welded specimens.

\begin{tabular}{c|c|c|c}
\hline Welding & UTS, MPa & Yield Strength, MPa & Elongation to failure, \% \\
\hline Oxy-Hydrogen & 317 & 240 & 33.4 \\
Oxy-Acetylene & 357 & 270 & 32.5 \\
\hline
\end{tabular}




\subsection{Hardness Measurements}

Hardness values in specific regions on the weldments are shown in Table 3 . The type of welding technique plays very important role on the hardness values in the material. Oxy-acetylene welded specimen has significantly higher hardness values compared with the counterpart. Besides, particular regions affect the hardness values, which have the highest in the fusion zone for both of weldments where melting occurs and structure completely changed due to the rapid solidification. In this region, precipitations of pearlite and cementite can occur, and those structures may enhance the hardness values. Besides, carbon diffusivity in the heat-affected zone (HAZ) may cause significant microstructural changes. One of the most crucial effects on hardness of the steel is the microstructure, which influences the tensile, impact and fatigue responses [14]. Second highest hardness values are obtained in the fine grain region where small grains act as a pinning effect and mobility of the dislocations. It has been concluded that there is a strong correlation between a materials mechanical properties and its hardness. In general, an increase in hardness resulted in high tensile response [15].

\subsection{Bending Test Results}

Bending is a part of the deformation in many other forming operations. The pictures of typical bending specimens are shown in Fig. 3. Both specimens were bended without any macrocracks. It can be said that both welded specimens perfectly joined. Bending characteristic of

TABLE 3. Measured hardness values for the specific regions.

\begin{tabular}{c|lc}
\hline Welding process & \multicolumn{1}{c}{ Regions } & Hardness, $H V$ \\
\hline \multirow{5}{*}{ Oxy-Hydrogen } & Base Metal & 120 \\
& Transition Zone & 123 \\
& Fine Grain Zone & 140 \\
& Coarse Grain Zone & 126 \\
& Fusion Zone & 172 \\
& Base Metal & 120 \\
& Transition Zone & 169 \\
Oxy-Acetylene & Fine Grain Zone & 204 \\
& Coarse Grain Zone & 190 \\
& Fusion Zone & 210 \\
\hline
\end{tabular}



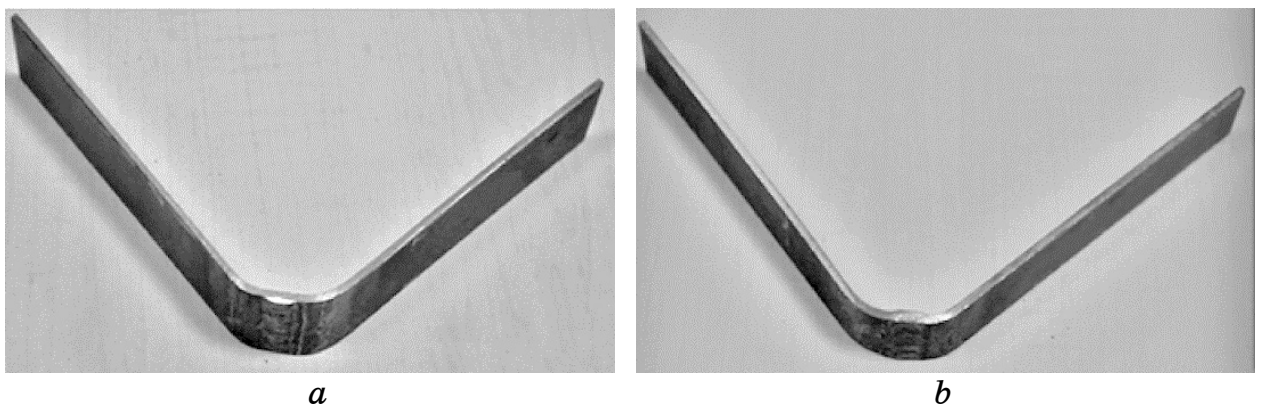

Fig. 3. Macro picture of the tested specimens: oxy-acetylene weldment $(a)$, oxy-hydrogen weldment $(b)$.

these specimens is mainly related to the ductility, which has quite close values for both of the welding technique. It is clearly seen that there is no significant difference between two specimens.

\subsection{Microstructure}

Oxy-acetylene welded specimen microstructure of the steel is shown in Fig. 4 and oxy-hydrogen welded specimen microstructure is shown in Fig. 5. It is clearly seen that there are five distinct regions, which are base metal, transition region, fine, coarse grain regions and fusion zones for both weldments. Base metal consists of white ferrite grains and relatively dark grey pearlite phases, which are located on the grain boundaries or adjacent to the grains. Most of grains are equiaxed and uniformly distributed. In the transition zone, specimen undergoes austenitic temperature and depending on the $\mathrm{C}$ and $\mathrm{Mn}$ content in this region resulted in the formation of upper bainite. In the fine grain region, sample obtains small amount of heat input, which is insufficient

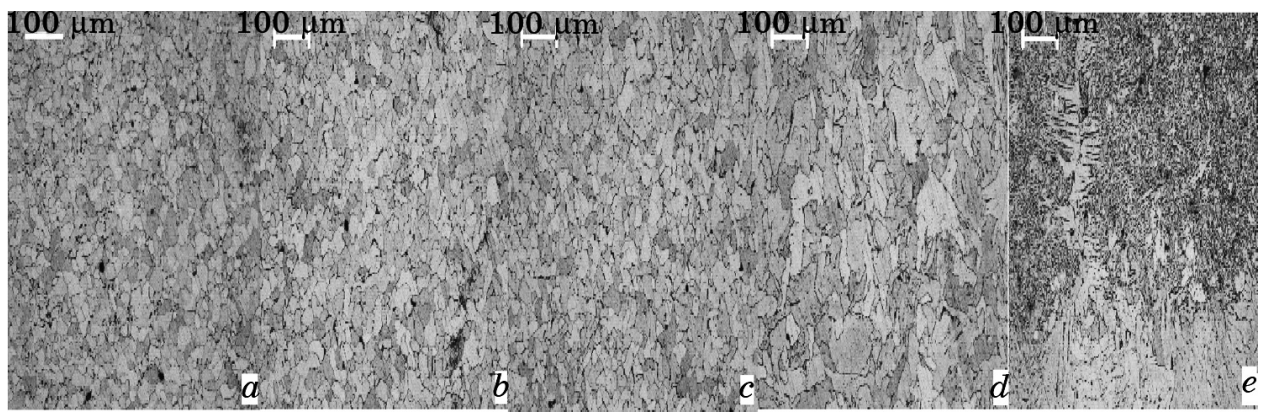

Fig. 4. Microstructure of oxy-acetylene welded specimen: base metal (a), transition zone $(b)$, fine grain region $(c)$, coarse grain region $(d)$, fusion zone $(e)$. 


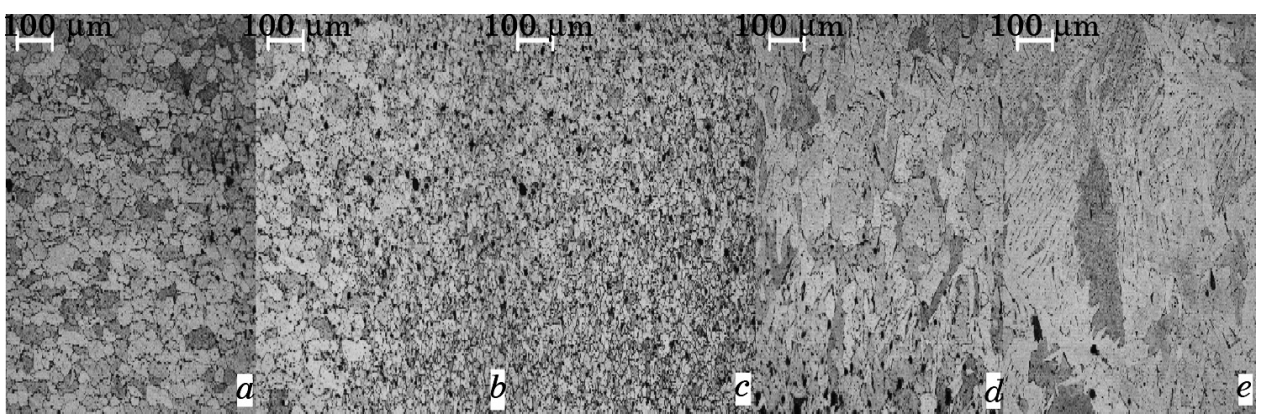

Fig. 5. Microstructure of oxy-hydrogen welded specimen: base metal (a), transition zone $(b)$, fine grain region $(c)$, coarse grain region $(d)$, fusion zone $(e)$.

for the grain growth. Relatively small ferrite and pearlite phases are evident in this region. In the coarse grain region, specimen suffers extremely high temperature, which causes the grain growth, and coarse pearlite and ferrite phases are common in this particular region. In general, the main deleterious effect caused by welding of the steel is excessive grain growth and formation of cementite, martensite, and pearlite with a high level of hardness in the HAZ, which are associated with the presence of carbon and tensile residual stresses, which cause cold cracking [16]. In the fusion zone, material is melted and rapidly cooled where Widmanstätten and acicular ferrite occurred. Widmanstätten plates are originated from the grain boundaries through the centre of the grains, but acicular ferrite (needle-like structure) is squeezed in the middle of the grains. Both specimen microstructures are very similar, except for fusion zone, where more coarse grains can be seen for the oxy-hydrogen welded specimen. Besides, higher porosity can be seen in the oxy-hydrogen welded specimen in the HAZ region, where hydrogen diffusivity plays significant role. Uygur and Gulenc [14] stated that an increase in $\mathrm{CO}_{2}$ content causes slight decrease in ductility, but caused improvements in tensile and yield strength. These increases can be attributed to solid solution strengthening by the formation of martensite and bainite in ferrous alloys.

\section{CONCLUSIONS}

In this study, following conclusions can be reached.

1. Oxy-acetylene welded specimens had significantly higher tensile response compared with the counterpart. The welding type does not influence the ductility.

2. The welding type significantly affects microhardness values of the particular regions. Hardness values are significantly higher in the oxy-acetylene welded specimen due to the carbon diffusion. 
3. Microstructure consists of five distinct regions, which are base metal, transition region, fine-grained region, coarse-grained region, and fusion zone.

4. Although the microstructures of both weldments are similar, there are slight changes in the fusion zone and HAZ depending on the hydrogen diffusivity.

5. Although some differences are observed in the mechanical properties and in the microstructure of the weldments, the results prove that oxy-hydrogen welding could be used in various applications as an alternative clean welding method compared with oxy-acetylene welding.

This study has been supported by Gazi University Scientific Research Project Section. Authors would like to thank to Gazi University for this support.

\section{REFERENCES}

1. H. Gerengi, Y. Kocak, A. Jazdzewska, M. Kurtay, and H. Durgun, Construction and Building Materials, 49: 471 (2013).

2. H. Ates and N. Kaya, Metallofiz. Noveishie Tekhnol., 35, No. 2: 241 (2013).

3. H. Ates, Metallofiz. Noveishie Tekhnol., 30, No. 7: 1009 (2008).

4. V. I. Yurhey, Welding International, 17, Iss. 5: 407 (2003).

5. E. Tezcan, VI National Congress Welding Technology TMMOB (Ankara: 2007), p. 11.

6. S. Anık, Welding Technique (Istanbul: ITU Faculty of Machine: 1980) (in Turkish).

7. H. Ates, M. E. Cakır, A. Kurt, M. Turker, and I. Uygur, Welding International, 28, Iss. 10: 762 (2014).

8. H. Ates, M. E. Cakır, A. Kurt, M. Turker, I. Uygur, and M. Koc, II European Conference and Workshop on Renewable Energy Systems (September 20-30, 2013 ) (Antalya: 2013).

9. S. Anık, Handbook of Welding Techniques (Istanbul: Welding Technology Edu. Res. and Test Ins. Gedik Edu. Foundation: 1991).

10. A. Kurt, H. Ates, I. Uygur, and M. Koc, Int. Conference on Investment Casting ICIC (India: 2010).

11. www.hidrojenerator.com (2013).

12. M. Dieter and D. Bacon, Mechanical Metallurgy (London: McGraw-Hill Book Company: 1988).

13. S.-M. Lei, T.-C. Kuang, X.-L. Cheng, S.-H. Yin, and H.-M. Zhu, New Carbon Materials, 22, Iss. 1: 70 (2007).

14. I. Uygur and B. Gulenc, Metalurgija, 43, No. 1: 35 (2004).

15. I. Uygur, Industrial Lubrication and Tribology, 58, Iss. 6: 303 (2006).

16. A. Roshanghias, A. H. Kokabi, M. Barzegari, and H. R. M. Hosseini, $1^{\text {st }}$ Int . Conference on Welding Technologies (June 11-13, 2009, Ankara) (Ankara: 2009). 